\title{
The Impact of Non-Oil Exports on Balance of Payment Disequilibrium in Nigeria
}

\section{${ }^{1}$ Paul Adeniyi Adeyemi, and ${ }^{2}$ Kayode Adewumi Aladesanmi}

\author{
${ }^{1}$ Department of Economics, Ekiti State University, Ado-Ekiti, Nigeria. \\ ${ }^{2}$ Dept. of Business Administration \& Management, Federal Polytechnic, Ado-Ekiti, Nigeria.
}

\begin{abstract}
The over-reliance on oil export revenue with little attention to non-oil export has subjected the Nigerian economy to recurring adverse external shocks which further aggravate the problem of balance of payment deficit in Nigeria. Therefore, study set out to examine the impact of non-oil exports on balance of payment disequilibrium in Nigeria. The data used for this study is secondary in nature and it spans from 1970 to 2018. The study employed econometric tools of ARDL Cointegration analysis and ARDL Error Correction Model to explore the long run relationship and the impact of non-oil exports on balance of payment disequilibrium respectively. The result of Wald bound test revealed that there is existence of co-movement between non-oil exports and balance of payment while long run ARDL Error Correction Model results showed that non-oil export has significant negative impact on balance of payment disequilibrium. In the same vein, inflation and interest rate also have negative impact on balance of payment disequilibrium but interest rate is insignificant. Findings from the study also exhibited positive relationship between exchange rate, trade openness and balance of payment. However, the positive impact of exchange rate on balance of payment is significant while that of trade openness is not significant. The study, thus concluded based on the findings that the non-oil export has not been contributing positively to improve the balance of payment position in Nigeria. In line with these findings, the study recommended that government should devise plans and strategies of boost the non-oil export sectors such as agricultural, manufacturing, solid minerals and service sectors in order to build virile and strong non-oil export sectors that can achieve favourable balance of payment. Moreover, the citizens of Nigeria should be motivated by one way or the others to have a taste for locally produced goods.
\end{abstract}

Keywords: Non-Oil Exports, Balance of payment (BOP), Deficit and ARDL Model

\section{How to Cite:}

Adeyemi, P. A., and Aladesanmi, K. A. (2022). The Impact of Non- Exports on Balance of Payment Disequilibrium in Nigeria. International Journal of Finance Research, 3(1). 1 - 9 DOI: https://doi.org/10.47747/ijfr.v3i1.585 


\section{Introduction}

Foreign trade is seen as an engine of growth in any economy across the globe. There is a great deal of empirical evidence to suggest that it is impossible to understand the economic performance of a country without reference to their trading sector, that is, the performance of exports relative to the propensity to import. Consequently, the role of balance of payment (BOP) cannot be over emphasized in the growth and development of a nation. Balance of payment of a country is a systematic record of all its economic transaction with the outside world in a given year. It involves the receipts (exports) and payments (imports) in the international transactions of a country. Balance of payment statistics is useful for a number of policies. At a national level, they provide a variable input for the conduct of monetary, financial, fiscal and structural policies. At international level, they are valuable sources of information for designs of mechanism to prevent and resolve crisis (African Review, 2004). Among the developing countries in which Nigeria is involved, there is prevalence of persistence balance of payment deficit which is the major cause of concern to these economies. Balance of payment weakness in Nigeria is caused by low level of agricultural production, low level of technological development, inadequacies of import substitution and export promotion strategies, low inflow of foreign direct investment, large fiscal deficit, external debt amortization, etc (Obioma 2008)

Balance of payment disequilibrium may be either a deficit or a surplus. The disequilibrium in deficit or unfavourable when the autonomous (debit) payments exceed autonomous (credit) receipts and vice versa (Jhingan 2013). It has been acknowledged that every government regime desires a right balance of payment position; this has raised a pertinent question concerning the policies to achieve favourable balance of payment (Odularo 2009). The importance of export to a nation's economic program and development has remained paramount. Export serves as a catalytic necessity for the overall development of an economy (Abon-Stait, 2005). There are two major components of export in Nigeria. Oil export and non-oil export. The non-oil export which is the focus this study are those commodities excluding crude oil (petroleum product) which are sold in the international market for the purpose of revenue generation. Nigeria's non-oil export is structured into broad four constituents which are agricultural exports, manufacturing exports, solid mineral export and service exports, manufacturing exports, solid mineral export and service export (Akeem 2011). Nigeria export promotion Council (NEPC) which was set up in 1976 to increase nonoil export as means of diversifying Nigeria's source of foreign exchange earning outlined the importance of non-oil export as a source of income to the economy which can be used to finance other economic sector of the nation; it creates employment opportunity for the populace and improve the well- being of the people. The evolution of export sector in Nigeria right from independence day staged that in the decades of 1960's and 1970's, the bed rock of Nigeria economy was agricultural export such products like cocoa, palm produce, groundnut and rubber and cotton (CBN 2011). On the basis of the importance of export sector to the economy, this study finds its imperative to delve into the impact of non-oil export on the balance of payment disequilibrium in Nigeria.

\subsection{Motivation}

The over -reliance on oil export in Nigeria as a means of generating revenue for the country's survival has been a concern and a source of worry. Oil sector accounts for over $90 \%$ of 
Nigeria's total export while non-oil export accounts for less than 10\%. The non-oil export falls from 40\% in 1979 to 50\% in 2010 (John and Ogege, 2010). The volatility in oil price in the world market has been creating economic crisis since 1982 till date. There was a slump in oil price in 1982, the beginning of dwindling of oil prices in Nigeria, also in 1986 followed the sudden collapse of international oil price in 2014 and the consequent fall in foreign exchange have created serious challenges such as high level of unemployment, poverty of the highest order, inequalities of income and opportunity and chronic balance of payment deficit. These crises were emanated from excessive dependence on oil export and as a single dominance export commodity. This extreme reliance on oil export revenue has subjected the Nigerian economy to recurring adverse external shock which further intensifies the problem of balance of payment deficit in Nigeria. It is a goal of every government to place her economy on the right path of balance of payment equilibrium, therefore, government of Nigeria embarked on various policies, programmes and institutions to boost the rate of export from non-oil sector to ensure favourable balance of payment in the Nigerian economy. Government introduced SAP in 1986 to restructure and diversify the productive base of the economy by curtailing Nigeria's over reliance on the oil sector and also to promote export of non-oil commodity as a source foreign exchange. NEPC was also set up in 1979 to promote export structure and to advance credit to non-oil export sector. The National Economic and Empowerment Development strategy (NEEDs) in 2004 was designed to boost non-oil export and so on. Despite all the government efforts and various policy instruments put in place by the successive governments, balance disequilibrium in Nigeria still remained persuasive. The growth of economic performance also remained slow and unimpressive.

\subsection{Main Contribution to Knowledge}

This paper has pushed the frontier of knowledge in insightful ways, there were several studies carried out on the relationship between non-oil export and economic growth but research works on the study between non-oil export and balance of payment disequilibrium is very rare in the literature. Most of the studies done on the relationship between non-oil export and balance of payment disequilibrium applied Ordinarily Least Square (OLS) method. The beauty of this study is that this study used recent econometrics tools of ARDL cointegration and Error Correction Model to explore the impact of non-oil export on balance of payment disequilibrium.

The rest of the paper is organized in five sections. Section two is devoted to the review of related literature, while section three deals with research methods. Section four presents the results and discussions, while conclusion and recommendations are presented in the last section.

\section{Literature Review}

Aremu (2016) investigated the role of oil and non-oil exports on the Nigerian economy over the period of 1981 to 2015. The ADF and PP unit root test, Johansen cointegration test, Granger causality test, impulse response functions (IRF) and variance decomposition (VD) were used in the analysis of the study. The cointegration test indicates that GDP, Oil and Nonoil exports were co integrated. The Granger causality test indicates short run unidirectional causality running from oil export to GDP. There are also bidirectional long runs causality relationship between oil export and GDP, and unidirectional long run causality running from 
non-oil export to GDP. The study result indicates that oil exports have inverse relationship with economic growth while non-oil exports have positive relationship with economic growth.

Samson and Abdulwahab (2014) examined determinants of non-oil export and economic growth in Nigeria. The bound test approach was explored to examine the long run and short run effects of the non-oil export and its ensuing determinants. The result reveals significant effects of non-oil export on economic growth in the long and short run.

Azubike (2016) analysed the balance of payments and policies that affect its positioning in Nigerian economy. The tariff, non-tariff and exchange rate policies were used as policies that affect the balance of payments. The study employed the Ordinary Least Square(OLS) methods of estimation and the heteroscedacity and autocorrelation covariance(HAC) in order to avoid spurious regression results.. The result showed that the indirect tax, export and exchange rate satisfy the a priori expectation.

Kaur (2011) employed Panel data analysis to examine the non-oil sector contributions to balance of payment equilibrium in USA with Asian partner. The variables used to assess the study were openness and corruption index. Random effects estimated revealed that openness was not significant in the balance of payment equilibrium.

Bahmani-Oskooee (2011) examined the long-run response of Middle Eastern Countries balance of payment to the development of the non-oil sector. He used Johansen Cointegration analysis as econometric technique to explore the relationship between non-oil export and balance of payment. The result showed that there is existence of favourable long-run effect of non-oil sector on balance of payment across the seven countries involved.

Ogunsanwo, Obisesan and Olowo (2016) examined the short run and the long run effects of non-oil trade export in economic growth in Nigeria. The study utilized descriptive and inferential statistics (unit root, Johansen cointegration and error correction model) to explore the study. The study showed that non-oil total trade export, balance of trade and exchange rate have positive and significant effects on economic growth while inflation rate has no significant effect on economic growth in Nigeria.

Kawai (2017) used cointegration analysis to investigate the impact of the non-oil exports on Nigerian economy using annual data between 1980 and 2016. The study showed that there is a strong evidence of co-integration relationship between non-oil exports and economic growth in Nigeria.

Okeke (2018) employed multiple regressions and correlation analysis to investigate the effect of imports and exports on balance of foreign trade in Nigeria between the period 2007 and 2016. The study used Gross Domestic Product (GDP) as dependent variable while imports, exports and openness are the independent variables. The findings from the study revealed that import has positive and significant impact on balance of foreign trade in Nigeria (GDP) while exports and openness have insignificant positive effect on balance of foreign trade in Nigeria (GDP).

Iwuoha and Chigozrian (2019) examined the impact of non-oil export on economic growth in Nigeria. The study employed ARDL model to estimate the short and long run relationship between the two variables. The ARDL result revealed that all the variables tend to move 
together in the long run. The study also showed that the impact of non-oil export is not significant on the economic growth in Nigeria.

Familusi (2020) employed simple random sampling technique through the use of structured questionnaire to analyse the challenges undermining the promotion of non-oil export in Nigeria. The finding of the study showed that poor access to finance is a major impediment to the promotion of non-oil export in Nigeria. The result of the study also revealed that lack of continuity in export policies discourage the promotion of non-oil export, thereby undermining the performance of non-oil sector export in Nigeria..

Esiaka, Uwaleke and Amane (2021) examined the impact of non-oil foreign trade on economic growth in Nigeria. The study adopted ex-post facto research design. The study employed vector error correction model (VECM) to investigate and analyze the long run and short run impact on non-oil export on economic growth. The results showed that in the short run, increase in non-oil import leads to increase in the GDP while increase in non-oil export leads to decrease in GDP. The results indicate that there is positive impact of non-oil import on GDP and negative impact of non-oil export on GDP.

\section{Research Methods}

\subsection{Model Specification}

Based on theoretical review and empirical consideration, this study followed the absorptive theory of balanced of payment and also adopted the model of Ogunsanwo et.al (2020) with modifications. The model for this study is thus specified as follows:

$\mathrm{BOP}=\mathrm{f}(\mathrm{NOEX}, \mathrm{EXCR}, \mathrm{OPEN}, \mathrm{INF}, \mathrm{RINT})$

Explicitly, it is re-stated as below:

$\mathrm{BOP}=\alpha_{0}+\alpha_{1} \mathrm{NOEX}+\alpha_{2} \mathrm{EXCR}+\alpha_{3} O P E N+\alpha_{4} I N F+\alpha_{5} I N T+\mathrm{u}_{\mathrm{t}}$

Where

$\mathrm{BOP}=$ Balance of payment

NOEX= Non- Oil Exports

$\mathrm{EXCR}=$ Exchange Rate

OPEN= Trade Openness

$\mathrm{INF}=$ Inflation Rate

RINT $=$ Real Interest Rate

$\alpha_{0}=$ intercept

$\alpha_{1}-\alpha_{4}=$ parameters to be estimated

$\mathrm{u}_{\mathrm{t}}=$ error term 


\subsection{Estimation Techniques}

This study employed ARDL Error Correction Model to examine the impact of Non Oil Exports on Balance of payment disequilibrium in Nigeria. ARDL Cointegration was used to analyze the existence co-movement between Non Oil Exports and Balance of payment disequilibrium in Nigeria. In line with Guajarati (2009), the Argumented Dickey Fuller (ADF) test was employed to test for the unit root and to determine the stationarity.

\subsection{Sources of Data}

The data used for this study was secondary in nature. The data like Non Oil Exports, Exchange Rate, Trade Openness, inflation Rate, Real Interest rate were sourced from the CBN publications, Central Bank of Nigeria statistical bulletins and National Bureau of Statistics between 1986 and 2018.

\section{Data Analysis Discussion}

Table 1. ADF Unit Root Test

\begin{tabular}{lllcc}
\hline Variable & Deterministic term & @ Level & @ Diff. & Remark \\
\hline Balance of payment & Constant & -1.95 & $-5.35^{* * *}$ & $I(1)$ \\
& Constant and Trend & -1.54 & $-5.50^{* * *}$ & $I(1)$ \\
Non-Oil export & Constant & -0.50 & $-7.01^{* * *}$ & $I(1)$ \\
& Constant and Trend & -2.87 & $-6.96^{* * *}$ & $I(1)$ \\
Exchange rate & Constant & -2.09 & $-5.21^{* * *}$ & $I(1)$ \\
& Constant and Trend & -1.25 & $-5.61^{* * *}$ & $I(1)$ \\
& & & & \\
Trade openness & Constant & -2.31 & $-7.48^{* * *}$ & $I(1)$ \\
& Constant and Trend & -2.37 & $-4.66^{* * *}$ & $I(1)$ \\
& & & & \\
Inflation rate & Constant & $-2.92^{*}$ & $-5.67^{* * *}$ & $I(0)$ \\
& Constant and Trend & $-4.02^{* *}$ & $-5.61^{* * *}$ & $I(0)$ \\
& & & & \\
Real interest rate & Constant & $-7.27 * * *$ & $-9.82^{* * *}$ & $I(0)$ \\
& Constant and Trend & $-7.48^{* * *}$ & $-9.59^{* * *}$ & $I(0)$ \\
\hline
\end{tabular}

Source: Author's computation, 2021

*** $p<0.01 ; * * p<0.05 ; * p<0.1$

The result of the Augmented Dicky Fuller (ADF test) revealed that balance of payment, Nonoil export, exchange rate and trade openness were stationary at first difference while all other variables attained stationarity at level. The order of integration at which stationarity is attained determines the estimation of technique suitable for each model. Based on above scenario, the study employed ARDL model towards achieving the aim of this paper. 
Table 2. ARDL Bound Test

\begin{tabular}{|c|c|c|c|c|c|c|c|c|}
\hline Test & Statistics & & 200170 & & 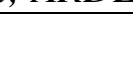 & & \\
\hline F-stat & \multicolumn{2}{|c|}{3.983} & & & & & & \\
\hline t-stat & \multicolumn{2}{|c|}{-2.103} & & & & & & \\
\hline \multicolumn{9}{|c|}{ Kripfganz and Schneider (2018) critical values and approximate p-values } \\
\hline & \multicolumn{2}{|c|}{$10 \%$} & \multicolumn{2}{|c|}{$5 \%$} & \multicolumn{2}{|c|}{$1 \%$} & \multicolumn{2}{|c|}{ Probability value } \\
\hline & $\mathrm{I}(0)$ & $\mathrm{I}(1)$ & $\mathrm{I}(0)$ & $\mathrm{I}(1)$ & $\mathrm{I}(0)$ & $\mathrm{I}(1)$ & $\mathrm{I}(0)$ & $\mathrm{I}(1)$ \\
\hline $\mathrm{F}$ & 2.032 & 3.262 & 2.484 & 3.874 & 3.571 & 5.325 & $0.006 * * *$ & $0.044 * *$ \\
\hline $\mathrm{T}$ & -1.615 & -3.488 & -1.975 & -3.905 & -2.695 & -4.744 & $0.038 * *$ & 0.501 \\
\hline
\end{tabular}

Table 2 above shows the ARDL bound test for our specified ARDL model. The calculated bound test F-statistics are significant at 5\% and $10 \%$ conventional levels; hence, we may conclude that the long run relationship exists between non-export, exchange rate, trade openness, inflation, interest rate and balance of payment. Hence, the study proceeds to the long-run and short-run-error correction models (ECM).

Table 3. Long run and Short ARDL Estimates Estimated ARDL Parameters

\begin{tabular}{|c|c|c|c|c|}
\hline Variable & Coefficient & Std. Error & t-Statistic & Prob. \\
\hline noex $_{t-1}$ & -2.404 & 1.316 & -1.830 & $0.077 *$ \\
\hline$e x r_{t-1}$ & 1.881 & 1.099 & 1.710 & $0.097 *$ \\
\hline$t o_{t-1}$ & 0.013 & 0.451 & 0.030 & 0.978 \\
\hline$i n f_{t-1}$ & -0.861 & 0.679 & -1.270 & 0.214 \\
\hline $\operatorname{rint}_{t-1}$ & -1.752 & 1.229 & -1.430 & 0.164 \\
\hline$\Delta$ noex $_{t}$ & -0.570 & 0.153 & -3.720 & $0.001 * * *$ \\
\hline$\Delta e x r_{t}$ & 0.446 & 0.167 & 2.670 & $0.012 * *$ \\
\hline$\Delta t o_{t}$ & 0.003 & 0.107 & 0.030 & 0.978 \\
\hline$\Delta i n f_{t}$ & -0.204 & 0.146 & -1.400 & 0.172 \\
\hline$\Delta r i n t_{t}$ & -0.415 & 0.212 & -1.960 & $0.059 *$ \\
\hline$e c m_{t-1}$ & -0.237 & 0.113 & -2.100 & $0.044 * *$ \\
\hline$R^{2}$ & $=0.44$ & & & \\
\hline
\end{tabular}

Regression diagnostic test results

$\begin{array}{lc}\text { LM-test } & =0.63[0.433] \\ \text { White-test } & =31.0[0.270] \\ \text { Stability } & =0.95[0.531]\end{array}$

Stability $=0.95[0.531]$

Source: Authors' computation. $* * * p<0.01 ; * * p<0.05 ; * p<0.1$

Table 3 showed both the long run and the short run ARDL estimates. The results revealed that in the long run and short run, non-oil export has significant negative impact on balance of payment disequilibrium. In the same vein, inflation and interest rate also have negative impact on balance of payment disequilibrium but interest rate is not significant in the short run. The 
study also exhibited positive relationship between exchange rate, trade openness and balance of payment. However, the positive impact of exchange rate on balance of payment is significant while that of trade openness is insignificant. The diagnostic test revealed that the results are insignificant which implies that there is no autocorrelation, no heteroscedacity and that the parameters are stable.

\section{Conclusion}

This study examined the impact of non-export on balance of payment disequilibrium in Nigeria. It used aggregate time series data sourced from CBN statistical bulletin and National Bureau of Statistics covering the period 1986 to 2018. Data collected were analyzed using the ARDL technique. The result of ARDL bound test revealed that there is existence of comovement between non-oil exports and balance of payment while long run ARDL Error Correction Model results showed that non-oil export has significant negative impact on balance of payment disequilibrium. Likewise, inflation and interest rate also have negative impact on balance of payment disequilibrium but interest rate is not significant. Findings from the study also exhibited positive relationship between exchange rate, trade openness and balance of payment. However, the positive impact of exchange rate on balance of payment is significant, after all, that of trade openness is not significant. The study, thus concluded based on the findings that the non-oil export has not been contributing positively to improve the balance of payment position in Nigeria.

In line with the findings, the study recommended that government should devise plans and strategies of boost the non-oil export sectors such as agricultural, manufacturing, solid minerals and service sectors in order to build virile and strong non-oil export sectors that can achieve favourable balance of payment. Moreover, the citizens of Nigeria should be motivated by one way or the others to have a taste for locally produced goods.

\section{References}

Abon-Stait, F.(2005). Are exports the engine of economic growth? An application of cointegration and causality analysis for Egyp, African Development Bank, Economic Research Working Paper No 76.

African Review (2004). The economic and business report 2003/2004: Walden Publishing Ltd.

Aremu, I.R.(2016). Analysis of the effect of oil and non-oil export on economic growth in Nigeria: https:// hal.archives-01401103.

Azubike, A.(2016). Balance of payments and policies that affects its positioning in Nigerian economy: https:// mpra. ub. uni-muenchen.de/74841/ MPRA Paper No74841

Bahma-Oskooee, M.(2011). Long run response of Middle East countries of balance of payment to development of non-oil sector: The $\mathrm{J}$-curve: A Literature Review. Journal of Applied Economics, 36(2), 1377-1398.

Central Bank of Nigeria (2011).Annual report and financial statement for the ended December, 2010. 
Esiaka J. C, Uwaleke U and Awana S. A (2021). Impact of non-oil foreign trade on economic growth in Nigeria; International Journal of Development strategies in Humanities, Management and Social Sciences, 11(1), 30-42

Familusi, O. B.(2020). Challenges undermining the promotion of non-oil export in Nigeria: Open Journal of Economics and Commerce, 3 (I3), 1-10.

Jhingan M.L.(2013). International Economics, $6^{\text {th }}$ Edition: Vrinda Publication (P) Ltd. Delhi.

Kaur S.(2011). Determinants of export services of USA with its Asian Partners: A panel data analysis: Eurasian Journal of Business and Economics, 4(8), 101-117.

Obioma, E. C.(2008). Balance of payment and exchange rate management in Nigeria: Empirical evidence from monetary approach, NCEMA policy analysis series, 4(2), 1225.

Odularu, G.(2009). Nigeria- US trade relations in the non-oil sector, available at http:// ssrn.com/ abtract $=1281585$.

Ogunsanwo, F. O., Obisesan, O.G. and Olowo, S.O. (2016). Short run and long run effects of non-oil trade export on economic growth in Nigeria. ECONOMICA: 16(2), 239-254.

Okeke C. C.(2018). Effect of imports and exports on balance of foreign trade in Nigeria: Internatonal Journal of Economics and Financial Research, 4(11), 349-353.

Samson, A. and Abdulwahab, H. (2014). Examine the determinants of non-oil export and economic growth in Nigeria: Journal for the Advancement of Developing Economics,3(1), 60-71.

\section{Copyrights}

Copyright for this article is retained by the author(s), with first publication rights granted to the journal.

This is an open-access article distributed under the terms and conditions of the Creative Commons Attribution license (http://creativecommons.org/licenses/by/4.0/) 